\title{
Anaplastic Lesion
}

National Cancer Institute

\section{Source}

National Cancer Institute. Anaplastic Lesion. NCI Thesaurus. Code C36113.

A morphologic finding indicating the presence of a malignant cellular infiltrate

characterized by the presence of large pleomorphic cells, necrosis, and high mitotic activity in a tissue sample. 